EDITORIAL RBEP

Este número é quase todo dedicado a trabalhos que abordam estudos, análises e discussões sobre políticas de ação educacional que visam à superação de situações de não equidade e de desigualdades socioeducacionais na educação superior. Os quatro últimos artigos situam-se em outro foco, tratando da constituição da universidade, de aspectos da história da educação e de intervenções didáticas, mantendo a pluralidade característica da Revista.

Com o objetivo de motivar a discussão e a apresentação de estudos sobre ações afirmativas no ensino superior, foi feita uma chamada especial, divulgada entre pesquisadores, coordenadores de programas de pós-graduação e usuários da RBEP e do Em Aberto, também publicada nas formas impressa e eletrônica, nos seguintes termos:

Iniciativas diversas vêm sendo tomadas por várias instituições de educação superior e pelo Governo Federal visando ampliar o acesso a este nível de ensino e assegurar a permanência de uma nova clientela social. Várias universidades instituíram, por exemplo, cotas para negros ou cotas para egressos da escola pública, ou abriram novos campi em bairros onde se concentram camadas sociais mais baixas. Entretanto, carecem ainda de estudos que possam responder a questões que impulsionaram tais iniciativas, como: Houve ampliação da base social da educação superior, teria ela se diversificado? Se essa diversificação ocorreu, quais foram os principais grupos sociais alcançados? Como vem comportando-se o rendimento acadêmico do alunado que ingressou por meio dessas iniciativas, comparado ao de seus colegas? Houve 
mudanças institucionais para o recebimento desses novos grupos? Tais mudanças se cingiram à organização administrativa ou se expressaram também em projetos pedagógicos? Houve repercussões financeiras, e, se ocorreram, de que ordem foram?

A comunidade acadêmica correspondeu à chamada, e dezenas de textos foram submetidos à avaliação. Os artigos constantes neste número foram os indicados pelos consultores ad hoc e pela Editoria Científica, em avaliação cega. As abordagens são variadas, trazendo contribuições de diferentes naturezas para a discussão dessas políticas e enriquecendo o conhecimento sobre ações afirmativas, democracia, pobreza, interculturalidade, etnias, juventude, papel das universidades e demandas contemporâneas. Restam muitas questões a responder e aspectos a tratar, o que certamente alimentará vários outros estudos.

Para gestores atentos e compromissados, estudos oferecem rica contribuição para uma compreensão ampla e, ao mesmo tempo, aprofundada de processos que favoreçam a equidade social, o que pode reverter salutarmente em guia e inspiração para políticas de ação que visem criar condições sociais mais igualitárias. Como se ressalta no primeiro artigo deste número, há uma relação de "infinita responsabilidade para com o excluído, uma vez que a sociedade, através de todos, é corresponsável nesse processo de cumprimento democrático", não deixando o Estado eximir-se, porém, de seu papel no investimento para a materialização dos direitos sociais, entre eles, fundamental, o da educação, que precisa ser fortemente dirigida para, como se pondera no artigo sobre pobreza e ações afirmativas, "diminuir o impacto da origem socioeconômica no desempenho escolar, de uma forma geral, a partir da escola básica". A parcela popular nessa condição está demandando uma nova perspectiva, a de um "devir popular", como colocado no ensaio sobre "Cultura e resistência: a criação do popular e o popular como criação" - "[uma] força imanente à vida que resiste incessantemente, porque recusa submeter-se a todas as formas de morte". Como defende Anísio Teixeira em belo poema: "Educação é vida."

Para concluir, como apontado no segundo artigo, não se pode abrir mão do apoio e do compromisso da sociedade civil para alterar as relações que favorecem as grandes desigualdades, "até porque é nas suas arenas que muito se joga o futuro imaginado de convivialidade e interculturalidade entre pessoas pertencentes a culturas diferentes".

\section{A Editoria Científica}

